\title{
HOW DO BINUS UNIVERSITY FRESHMEN APPRAISE ENGLISH ENTRANT? (A QUALITATIVE APPROACH)
}

\author{
Almodad Biduk Asmani \\ English Departement, Faculty of Humanities, BINUS University \\ Jln. Kemanggisan Ilir III No.45, Kemanggisan - Palmerah, Jakarta 11480 \\ aasmani@binus.edu
}

\begin{abstract}
The research examined the assessments and the comments provided by Binus University freshmen students concerning their study experiences of taking University English Entrant as part of their compulsory English course program at Binus during the odd semester of 2010/2011. The goals of the research were to find out whether such program had been useful and effective for these students in terms of the teaching quality, course contents, and independent learning system commonly applied at Binus University. The research applied the technique of qualitative approach with the focus on finding the general feedback of these students in evaluating the program based on free-response data. In the initial stage of the research, the writer selected the random sample of four to five English Entrant classes ranging from small to large number of students. The writer then distributed the questionnaires to the subjects. After the data had been collected, the writer tabulated, summarized, and interpreted the data in the discussion. The final result indicates that communicative teachers are always the best preference; communicative tasks that put emphasis on fluency and clarity, rather than accuracy, have always been appreciated highly; and feedback in learning is highly expected for the independent learning system.
\end{abstract}

Keywords: freshmen students, appraise English, English entrant

\begin{abstract}
ABSTRAK
Penelitian menguji penilaian dan komentar yang diberikan mahasiswa baru Binus University mengenai pengalaman studi mereka mengikuti kelas University English Entrant sebagai bagian dari program kursus bahasa Inggris wajib di Binus selama semester ganjil 2010/2011. Penelitian bertujuan untuk mengetahui apakah program tersebut telah bermanfaat dan efektif bagi para siswa dalam hal kualitas pengajaran, materi kursus, dan sistem pembelajaran mandiri yang secara umum diterapkan di Binus University. Penelitian menerapkan teknik pendekatan kualitatif dengan fokus mencari umpan balik umum siswa dalam mengevaluasi program berdasarkan data respons-bebas. Pada tahap awal penelitian, penulis memilih sampel acak dari empat sampai lima kelas University English Entrant mulai dari kelas kecil hingga kelas besar. Penulis kemudian membagikan kuesioner kepada subjek. Setelah data terkumpul, data ditabulasikan, diringkas, dan ditafsirkan dalam diskusi. Hasil akhir menunjukkan bahwa guru komunikatif selalu menjadi preferensi terbaik; tugas komunikatif yang menekankan pada kelancaran dan kejelasan, daripada akurasi, selalu dihargai tinggi; dan umpan balik dalam pembelajaran sangat diharapkan untuk sistem pembelajaran mandiri.
\end{abstract}

Kata kunci: mahasiswa baru, penilaian bahasa Inggris, English Entrant 


\section{INTRODUCTION}

Freshmen students of the past semester of 2010/2011 have become the first generation to experience the teaching and learning process of the new English MKU with its first 2-credit-subject called English Entrant. In general, the three subjects in the New English MKU have been designed to focus less on grammar instruction, and instead, focus more on communicative activities. Thus, in the classroom, students are actively involved in more communicative tasks, such as conversations, presentations, and discussions. Twice a semester, they are also asked to produce an academic essay on a given topic. Outside the classroom, students are expected to practice their TOEFL iBT reading and listening activities in the labs, libraries, and at homes by using their textbook's CD ROM. Many comments, input, criticism, suggestions have been given by the lecturers so as to evaluate the usefulness as well as the effectiveness of such program. However, students might have different points of view from their lecturers. As students are the direct subjects of the teaching and learning process who received the advantages, as well as the disadvantages of the new program, then the writer needs to gain information about how they would evaluate the learning experiences they had with English Entrant. The writer assumes that if the students are already satisfied and happy with the ongoing process, then the next step would be to indicate the degree of success that these students have achieved. Of course, teachers' comments and input are highly appreciated, and thus contributing to the assessment process of the program. However, students' feedback is critical too, as it gets harder and harder to allow students enjoy their learning experiences these days, not to mention that it becomes wider and wider gap between the teacher expects and the students prefer.

The purpose of the research is to find out how students of Binusian 2014 appraise the teaching and learning process in English Entrant in terms of its usefulness under the contexts of its teaching process, course contents, and independent learning system. Therefore, the research project aims to find out in what aspects they may think useful in terms of the teaching process, course contents and beyond-class learning activities; they may think not useful in terms of the teaching process, course contents and beyond-class learning activities; what suggestions or input they may give regarding the teaching process, course contents and beyond-class learning activities.

The study has some significant effects on the following aspects. For teachers, the students' feedback can tell teachers about how far their teaching techniques and styles are acceptable in the students' perspectives. The information can help teachers consider improvement or maintenance of some aspects of their personal approaches in teaching. For curriculum designers, these students' comments can give input on how far these students are satisfied with the learning outcomes, scope and sequence, material contents, tasks, and textbooks contained in the course outlines. For language center unit, these students' input can provide information on how well the independent learning system has helped them in supporting their learning experiences. These include SALLC (Self Access Language Learning Center), Library, and English Tutorial program.

\section{Literature Review}

The research project is based on some observations and studies about the application of Communicative Language Teaching (CLT) approach in Asian contexts, in which local cultural values and practices may be in direct conflict with the western teaching and learning ways. Siemon (2010:40) states: “...to promote international exchange, students' communicative competence needs to be improved." She further comments that the Chinese students' ways of memorizing a lot of vocabulary and grammar rules do not adequately help them develop the necessary skills and abilities for general communication orally and in written (2010:41). 
McCombs in Brown (2003:50) said that the focus of a learner-centered approach is on individual learners' heredity, experiences, perspectives, backgrounds, talents, interests, capacities and needs. Interestingly, she defined learner-centered as a "foundation for clarifying what is needed to create positive learning contexts to increase the likelihood that more students will experience success". Richard (2001:223) states: "Learning is not the mirror image of teaching. The extent to which teaching achieves its goals will also dependent on how successfully learners have been considered in the planning and delivery process."

Richards specifies four biggest factors that contribute significantly to achieve quality teaching in a language institution. They are institutional factors, teacher factors, teaching factors and learner factors. In his opinion, a sound curriculum has one feature of "the range of courses offered corresponds to the needs of the learners" (Richard, 2001:204). For teacher factor, Richard (2001:213) mentions orientation, adequate materials, and course guides as part of the support for teachers.

For the teaching factor, Breen (in Richard, 2001) also gives examples of teachers' principles where most of the statements in the list focusing on the learner's interests, including: enabling the learners to use, addressing learners' mental-processing capacities, making the learners internalize and remember, taking account of learners' affective involvement, directly addressing learner's needs or interests, monitoring learner progress and providing feedback, facilitating learner responsibility or autonomy, managing the lesson and the group.

In evaluating the teaching process, Richard (2001:221) mentions some aspects of this appraisal system, including "lesson plan, teacher-made classroom materials, course outlines, and class assignments”. Richard (2001:223) states:

"It is important to ensure that the learners understand the goals of the course, the reason for the way it is organized and taught, and the approaches to learning they will be encouraged to take. It cannot be simply assumed that learners will be positively disposed toward the course, will have the appropriate skills the course demands, or will share the teacher's understanding of what the goals of the course are."

Richard (2001:224) further adds: "a questionnaire on preferred learning styles, classroom activities, and teaching approaches can be used to identify learners' learning style preferences".

Concerning motivation, Richard (2001) highlights the importance of learners' motivation in taking a course. Harmer (2007:100-104) further explains about the four different types of environment that teachers can develop to increase their students' level of motivation. These include: affect, where students are more likely to remain motivated if their teachers care enough for them by showing interest, consideration, respect, etc.; achievement, where students are more likely to stay motivated if they can feel a real sense of achievement in doing the tasks that they can succeed in; attitude, where students are likely to sustain their motivation if they can have full confidence in their teacher concerning what to teach and why to teach that particular lesson; activities, where students are likely to stay healthy in their motivation if they can feel engaged with the kinds of activities their teacher is trying to bring into their class, and how far the purposes of this activity match with what the students need; agency, where students are more likely to stay motivated if they can have a certain degree of ownership and responsibility to make decisions about what is going on in their learning.

Another component that contributes to the learners' success in language learning is the support system for course delivery. Harmer (2007) suggests an SAC, or Self-Access Center, for alternative to classroom learning. According to Harmer (2007), the characteristics of a good selfaccess center are classification system, pathways, training students, making self-access appropriate, and keeping their interests going. 
Harmer (2007:407-408) further provides suggestions on how to train students to adopt 'continued learning': 1) include 'continuing learning' as a topic in the syllabus, where teachers can involve students in awareness-raising activities, list all available sources that suits students' needs, suggest various skills that students need to do, as well as various styles of language study and language research that students can independently work on; 2) to arrange 'self-study' project in class where they can develop the habit of accessing kinds of materials on their own using the techniques discussed and practiced in class; 3 ) to negotiate "personal plans" which students can use after courses finish; 4) to encourage students to set up a discussion group; to encourage students to access many online resources for free language exercises and other materials.

\section{METHOD}

Research tried to find out the general opinion of the students in evaluating the usefulness of an English course they have studied during the odd semester of 2010/2011. After that, research tried to link their views in this regard with some related views in the ELT pedagogy. Research is aware that the 'creative and human aspects of social behavior' (Cohen et al., 2000) cannot be ignored. The students have other their own comments and input, particularly in evaluating the course. Therefore, research gave the students the opportunity to express their own thoughts and feelings in this regard.

Based on the nature of this knowledge, writer's position in this research project is more towards hermeneutic/interpretive epistemology, in which it assumes that all knowledge is "perspective-bound and partial, i.e. relative to that framework" (Usher, 1996). Based on the nature of this research, writer applied the approach of qualitative data gathering and analysis. By using a qualitative methodology in the research project, research focuses on a holistic interpretation, to understand the social phenomena by relying on participants' comments.

Research used survey questionnaires to collect the data, and the target population was all Binus students of 2014 who took English Entrant classes at Binus University in the odd semester of 2010/2011. To find out how the students evaluate the course usefulness, research used open-ended questions in regard to the teaching quality, the course contents and the beyond-class learning activities. The questions allow many possible responses regarding how the students evaluate the usefulness level of the English course they were taking to find out whether the program has met their needs and demands.

To anticipate different points of view that the students might have in the questionnaire, research provided open-ended questions to encourage them to express their individual opinions. These spaces for free comments compensate for the possible limitations of the quantitative procedure, namely the lack of sensitivity of the questionnaire to act in accordance with individual differences, nuances and tones in their responses as well as the danger of limiting their thinking to existing statements. Due to some considerations of the high response rate, non-respondents' exclusion, the spread of respondents and reasonable costs, research personally administered the questionnaire to the participants by asking the permission of time and opportunity from some English lecturers teaching their classes in the odd semester of 2010/2011 across campuses at Binus University.

Research divided the participants into two groups of Binusian freshman 2014 who took English subjects in the odd semester of 2010/2011 at Binus University, which are: Undergraduate students studying at Faculty of Computer Studies (120 students); Undergraduate students studying at other faculties (120 students), those are undergraduate students studying at Faculty of Economics and Business (40 students); undergraduate students studying at Faculty of Communication and Multimedia (40 students); undergraduate students studying at Faculty of Language and Culture (40 students). 
Binusians were chosen as the participants in the research project due to some reasons. First, all students of non-English department studying at Binus University must take English course as the compulsory subjects. This results in a large number of English-studying students who need a special academic consideration and treatment to meet the aims and objectives as expected. Second, because writer is the coordinator of English course program at Binus University, writer is in a better position to investigate any issue of the English course running in terms of the appropriateness and usefulness of the teaching methodology delivered, the curriculum designed and the beyond-class activities conducted.

For qualitative analysis, research used grids and matrices to organize the data. Then, research highlighted the themes, patterns, gaps and contradictions in the free comments of the participants, and summarized them into findings. The findings were analyzed and interpreted. The qualitative analysis answers the second, third and fourth research questions in terms of what other aspects they think useful or not useful in the English course system, as well as what suggestions or recommendations they could give for the improvement of the course system.

Of all the findings and interpretation found in the data, research examined aspects in the analysis that can be linked with the teaching approach, materials design and learning plan that is more in line with the demands and preferences of the students. Writer described the aspects, analyzed them, and interpreted them into a conclusion. Suggestions on each aspect of analysis for further development and future research are generated based on the summary of findings in the conclusion.

\section{RESULTS AND DISCUSSION}

\section{Data Presentation}

The responses of the computer and non-computer students in evaluating the teaching aspects of English Entrant are presented as Table 1. (the number in each bracket indicates the number of the respondents' voices).

Table 1 Summary of Computer and Non-Computer Students’ Responses to Teaching Aspect of English Entrant

\begin{tabular}{|c|c|c|}
\hline Attitudes & Computer Students & Non-Computer Students \\
\hline $\begin{array}{l}\text { Most } \\
\text { appreciated }\end{array}$ & $\begin{array}{l}\text { - } \quad \text { Likable way of teaching; communicative (29) } \\
\text { - } \quad \text { Good looking (2) } \\
\text { - } \quad \text { Good speaking (3) } \\
\text { - } \quad \text { Kind \& Friendly (2) } \\
\text { - } \quad \text { Socialize easily } \\
\text { - } \quad \text { Welcome students' inputs (2) } \\
\text { - } \quad \text { Timely assignments } \\
\text { - } \quad \text { Comfortable learning (4) } \\
\text { - } \quad \text { Listening skills } \\
\text { - Smart } \\
\text { - Sense of humor (2) }\end{array}$ & $\begin{array}{ll}\text { - } & \text { Likeable way of teaching: cool, } \\
\text { - } & \text { Strique (22) } \\
\text { - } \quad \text { Kind \& free (2) } \\
\text { - } \quad \text { Young and dynamic (4) } \\
\text { - } \quad \text { Socialize easily (6) } \\
\text { - } \quad \text { Simplicity mindset (4) } \\
\text { - } \quad \text { Good speaking: synchronized body } \\
\text { - } \quad \text { Good grooming (2) } \\
\text { - } \quad \text { Comfortable learning (3) } \\
\text { - } \quad \text { Knowledgeable \& Resourceful (3) } \\
\text { - } \quad \text { Sense of humor (7) } \\
\text { - } \quad \text { Great tips in speaking } \\
\text { - } \quad \text { Speaking skills } \\
\text { - } \quad \text { Listening skills } \\
\text { - } \quad \text { Writing skills }\end{array}$ \\
\hline
\end{tabular}




\begin{tabular}{|c|c|c|}
\hline $\begin{array}{l}\text { Least } \\
\text { appreciated }\end{array}$ & $\begin{array}{l}\text { - } \quad \text { too many assignments (9) } \\
\text { - } \quad \text { absence of Binusmaya upload (2) } \\
\text { - } \quad \text { too low speaking score } \\
\text { - } \quad \text { reading skills } \\
\text { - } \quad \text { too fast: listening }\end{array}$ & $\begin{array}{ll}\text { - } & \text { emergency substitute class (6) } \\
\text { - } & \text { GSLC activity } \\
\text { - } & \text { Too much } \\
& \text { assignments/presentations (2) } \\
\text { - } & \text { Minimum conversation with the } \\
& \text { lecturer } \\
\text { - } & \text { Early absences } \\
\text { - } & \text { Indonesian-English translation } \\
\text { - } & \text { Listening skills (3) } \\
\text { - } & \text { Reading skills (3) } \\
\text { - No feedback, esp. in writing \& } & \text { speaking }\end{array}$ \\
\hline Suggested & $\begin{array}{l}\text { - } \quad \text { Simplified assignments (2) } \\
\text { - } \quad \text { Scoring generosity (3) } \\
\text { - } \quad \text { More speaking opportunities } \\
\text { - } \quad \text { Don't rush } \\
\text { - } \quad \text { Give disciplines to trouble-makers } \\
\text { - } \quad \text { more listening practice in class }\end{array}$ & $\begin{array}{l}\text { - Keep it up or enhance (10) } \\
\text { - } \quad \text { Make teaching fun (2) } \\
\text { - } \quad \text { No more early absences } \\
\text { - Improved socializing skills (3) } \\
\text { - Improved sense of humor } \\
\text { - Improved teaching method } \\
\text { - } \quad \text { Changeved materials } \\
\text { - } \quad \text { Don't rush in speaking } \\
\text { - } \quad \text { More student-lecturer conversation } \\
\text { - } \quad \text { Games (2) } \\
\text { - } \quad \text { Be stricter (2) } \\
\text { - } \quad \text { Scoring generosity (4) } \\
\text { - } \quad \text { More speaking } \\
\text { - } \quad \text { Feedback for all skills }\end{array}$ \\
\hline
\end{tabular}

The responses of the computer and non-computer students in evaluating the course content of English Entrant are presented as Table 2 (the number in each bracket indicates the number of the respondents' voices).

Table 2 Summary of Computer and Non-Computer Student's Responses to the Course Content in English Entrant

\begin{tabular}{|c|c|c|}
\hline Attitudes & Computer Students & Non-Computer Students \\
\hline $\begin{array}{l}\text { Most } \\
\text { appreciated }\end{array}$ & $\begin{array}{l}\text { - Speaking skills (16) } \\
\text { - } \quad \text { GSLC (6) } \\
\text { - } \text { Materials :to the point, easy to follow (2) } \\
\text { - } \text { fearning methods: going home after } \\
\text { - } \quad \text { Teaching methods (5) } \\
\text { - Writing (4) } \\
\text { - } \quad \text { Sab visit } \\
\text { - } \quad \text { Writing scoring }\end{array}$ & $\begin{array}{l}\text { - } \quad \text { Writing skill: Essay (5) } \\
\text { - } \quad \text { GSLC (11) } \\
\text { - } \quad \text { Speaing home fast } \\
\text { - } \quad \text { Group conversill: drationa (22) } \\
\text { - } \quad \text { Listening methods (5) } \\
\text { - } \quad \text { Curriculum organization } \\
\text { - } \quad \text { Relax environment } \\
\text { - } \quad \text { Good lesson } \\
\text { - Class setting }\end{array}$ \\
\hline $\begin{array}{l}\text { Least } \\
\text { appreciated }\end{array}$ & $\begin{array}{ll}\text { - } & \text { difficult writing essays } \\
\text { - } & \text { listening skills and tests (13) } \\
\text { - } & \text { TOEFL (3) } \\
\text { - } & \text { Speaking skills (4) }\end{array}$ & $\begin{array}{ll}\text { - } & \text { Listening skill (13) } \\
\text { - } & \text { Too little absence (2) } \\
\text { - } & \text { Daytime schedule } \\
\text { - } & \text { Writing skill (3) }\end{array}$ \\
\hline
\end{tabular}




\begin{tabular}{|c|c|c|}
\hline & $\begin{array}{ll}\text { - } & \text { Too many presentations (4) } \\
\text { - } & \text { Reading skills (2) } \\
\text { - } & \text { Writing skill (3) } \\
\text { - } & \text { Listening skill: not clear } \\
\text { - } & \text { Lack of grammar }\end{array}$ & $\begin{array}{ll}\text { - } & \text { Reading skill and test (12) } \\
\text { - } & \text { Discussion group } \\
\text { - } & \text { Tests: TOEFL } \\
\text { - } & \text { Facilities: class speakers } \\
\text { - } & \text { Grammar (2) } \\
\text { - } & \text { Speaking } \\
\text { - } & \text { Textbook }\end{array}$ \\
\hline Suggested & $\begin{array}{ll}\text { - } & \text { Easy TOEFL (2) } \\
\text { - } & \text { More listening practice (6) } \\
\text { - } & \text { More lab visits (5) } \\
\text { - } & \text { Writing (3)? } \\
\text { - } & \text { Speaking (2)? } \\
\text { - } & \text { Reading? } \\
\text { - } & \text { Facilities: class speakers } \\
\text { - } & \text { More grammar lessons (2) } \\
\text { - } & \text { Games } \\
\text { - } & \text { More materials } \\
\text { - } & \text { Improve methodology }\end{array}$ & $\begin{array}{ll}\text { - } & \text { More absence proportion (2) } \\
\text { - } & \text { More grammar lessons } \\
\text { - } & \text { More materials to improve skills } \\
\text { - } & \text { More discussion group (2) } \\
\text { - } & \text { More learning tips \& strategies } \\
\text { - } & \text { Computer scoring } \\
\text { - } & \text { Easy \& short reading (3) } \\
\text { - } \quad \text { More student-lecturer conversation } \\
\text { - } \quad \text { Facilities: class speakers (2) } \\
\text { - } \quad \text { Keep it up (2) } \\
\text { - } \quad \text { Reading (2)? } \\
\text { - } \quad \text { Slower and clearer listening pace (6) } \\
\text { - } \quad \text { More listening practice (2) }\end{array}$ \\
\hline
\end{tabular}

The responses of the computer and non-computer students in evaluating the independent learning system of English Entrant are presented in Table 3 (the number in each bracket indicates the number of the respondents' voices).

Table 3 Summary of Computer and Non-Computer Student's Responses to the Independent Learning System in English Entrant

\begin{tabular}{|c|c|c|}
\hline Attitudes & Computer Students & Non-Computer Students \\
\hline $\begin{array}{l}\text { Most } \\
\text { appreciated }\end{array}$ & $\begin{array}{ll}\text { - } & \text { Writing GSLC (8) } \\
\text { - } & \text { Speaking? (5) } \\
\text { - } & \text { Writing? } \\
\text { - } & \text { Speaking tutorial/EESE (4) } \\
\text { - } & \text { English extra-curricular/BNEC (2) }\end{array}$ & $\begin{array}{l}\text { - } \quad \text { More freedom of learning (2) } \\
\text { - } \quad \text { Fun factor: games, movies, drama, music (7) } \\
\text { - } \quad \text { Listening (3)? } \\
\text { - } \quad \text { Serenity (2) } \\
\text { - } \quad \text { Hriting GSLC (5) } \\
\text { - } \quad \text { Learning through internet } \\
\text { - } \quad \text { Friend Discussion (3) } \\
\text { - } \quad \text { Speaking tutorial/EESE (6) } \\
\text { - } \quad \text { All independent learning (2) } \\
\text { - } \quad \text { Sistening tutorial outside labs (2) } \\
\text { - } \quad\end{array}$ \\
\hline $\begin{array}{l}\text { Least } \\
\text { appreciated }\end{array}$ & $\begin{array}{l}\text { - } \quad \text { Speaking tutorial /EESE (5) } \\
\text { - } \quad \text { Writing? } \\
\text { - } \quad \text { Reading (2)? } \\
\text { - Listening? } \\
\text { - Reading journal } \\
\text { - } \quad \text { Practening assignments at labs (2) } \\
\text { - English extra-curricular/BNEC (3) }\end{array}$ & 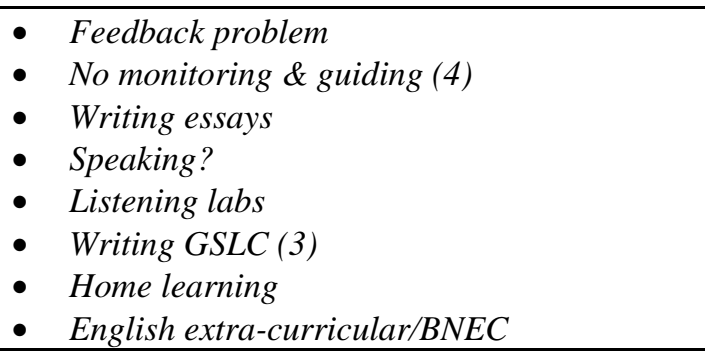 \\
\hline
\end{tabular}




\begin{tabular}{|c|c|c|}
\hline & & $\begin{array}{l}\text { - } \quad \text { Grammar \& pronunciation (2) } \\
\text { - } \quad \text { Listening (2)? } \\
\text { - Reading (6)? } \\
\text { - } \quad \text { Reading journal } \\
\quad \text { tutoriabsent tutoESE } \\
\end{array}$ \\
\hline Suggested & $\begin{array}{l}\text { - } \quad \text { Listening (3)? } \\
\text { - How reading be integrated in class } \\
\text { - } \quad \text { Writing? } \\
\text { - } \quad \text { Listening at lab (2) } \\
\text { - English extra-curricular/BNEC }\end{array}$ & 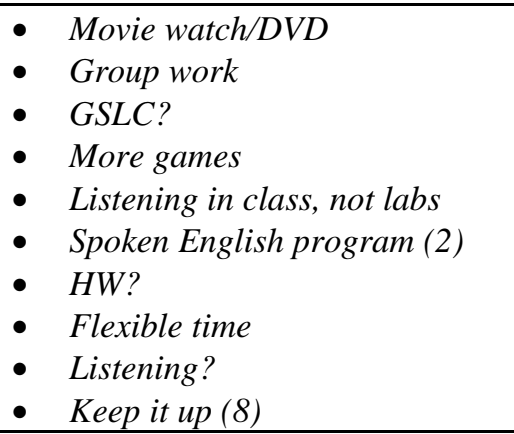 \\
\hline
\end{tabular}

\section{Data Summary}

In giving commendation to the teaching aspects of English Entrant, both computer and noncomputer students mostly appreciate the teaching way of the instructors with 29 and 22 voices respectively (total 51 voices). Sense of humor of the instructors also ranks high with the total of 9 voices. Specific characteristics of the instructors like kind-hearted and friendliness are also highly appreciated (total 9 voices). The ability of the instructors' skills to socialize with their students, his or her speaking competence as well as his or her ability to create comfortable learning environment are also appreciated (7 voices respectively). Other appreciative voices towards the instructors' characters include good looking/grooming (4 voices), knowledge and resource level (4 voices), young ages, high motivation, expressiveness, simplicity mindset, input welcoming, scoring generosity (2 voices respectively), and some of his or her language skills in listening, speaking and writing.

In giving criticism to the teaching aspects of English Entrant, both computer and noncomputer students less appreciate the amount of assignments given, especially speaking tasks in the class (total 11 voices). Next, absence in lecturers' class attendance and Binusmaya (Binus university intranet system) teaching activities are less appreciated (total 8 voices). Some ways of teaching reading and listening skills are also less appreciated (4 voices respectively). Other areas of criticism include tight scoring for speaking, minimum instructor's feedback especially for speaking and writing, and minimum conversation between instructor and students.

In giving suggestions on teaching aspects of English Entrant, both computer and noncomputer students think that the teaching methodology should be conducted as the way it is now, or even enhanced better (total 17 voices). Scoring generosity has also become the request among these students (total 7 voices). Other inputs towards the instructors include socializing skills, fun teaching, games, and discipline-giving (2 voices respectively).

In giving commendation to the course contents of English Entrant, both computer and noncomputer students mostly appreciate the speaking task format in the curriculum. They give 16 and 22 comments about this issue respectively (total 38 voices). Some students give 17 good comments about GSLC format. The format of essay writing receives 9 good comments. The teaching methodology used in the course also receives some good appreciation (6 voices). Other good inputs include the listening format ( 5 voices), the materials, the learning methods, the instructors, and the speaking scoring system (2 voices respectively). 
In giving criticism to the course contents of English Entrant, both computer and non-computer students least appreciate the listening format (total 26 voices). Next, some computer students do not really appreciate the amount and the format of the speaking tasks (8 voices). Some students also give criticism to the writing format (6 voices). Few computer students give negative feedback about TOEFL (3 voices), and few non-computer students give bad comments about grammar (2 voices).

In giving suggestions on the course contents of English Entrant, both computer and noncomputer students highlight the request that listening practice be improved in quantity and quality (total 12 voices). They also ask for more speaking or discussion activities (total 9 voices). Some noncomputer students focus more on the improvement of reading activities ( 7 voices). Some computer students ask for more laboratory visits (5 voices) and some improvements in writing activities (3 voices). Other inputs include easier TOEFL materials, more grammar lessons, improved facilities of class speakers, and simply, keeping the course as the way it does (2 voices respectively).

\section{Independent Learning System}

In giving commendation to the independent learning system of English Entrant, both computer and non-computer students mostly appreciate the speaking activities outside the classroom settings, such as speaking tutorial program (EESE), speaking extra-curricular program (BNEC), and friends chatting (total 24 voices). They also appreciate the writing activities on the GSLC sessions (total 14 voices). Some non-computer students also appreciate the fun factors integrated in the activities (7 voices). Few non-computer students value the reading activities at home (5 voices). Very few students think that everything in independent learning system is beneficial (4 voices), and that freedom of learning is an added-value in such activities (2 voices).

In giving criticism to the independent learning system of English Entrant, both computer and non-computer students do not give appreciation to the reading journal activities (11 voices). They also criticize the speaking tutorial program / EESE (total 7 voices) as well as the English extra-curricular program / BNEC (total 4 voices). Problems with monitoring and lack of feedback are also mentioned (6 voices). Some students disagree with listening assignments at laboratories (6 voices). Some students do not like the essay writing tasks on GSLC (5 voices).

In giving suggestions on the course contents of English Entrant, both computer and noncomputer students surprisingly encourage the existence of independent learning system (8 voices). Some suggested that listening tasks be done in classes rather than in laboratories (7 voices). Few still encourage group discussion through speaking tutorial and extra-curricular programs (4 voices). Very few suggested that reading tasks be done in classes rather than at homes (2 voices). Few non-computer students suggested more fun things be integrated in the activities, such as games, movie watch, etc (total 2 voices).

\section{Data Interpretation}

The teaching aspect in English Entrant receives the most comments from both computer and non-computer students, compared to other aspects. The biggest appreciation comes from the teaching method of the instructors, which are communicative language approach. Here, instructors are playing the roles more as facilitators rather than the lecturers. They usually encourage their students to focus more on fluency and clarity in their speaking practice rather than on accuracy. As a result, grammar is not the primary focus in the lessons. As long as grammar does not hinder or distract the meaning, lecturers tend to be okay with their students' performance. These factors might contribute to the highest appreciation from these students (total 51 voices). Specific characteristics of the instructors also receive positive comments, such as friendliness, kind-hearted and the ability to socialize with their students (total 16 voices). This means that these students appreciate more on lecturers who can mingle easily with them. They prefer to look at instructors not only as the one who can teach but also 
as the one who can play roles as their father/mother, older brother/sister, and sometimes friends. In other words, a certain degree of intimacy can be expected from these instructors' characters.

The highest criticism in the teaching aspects, but not the highest on other aspects, is on the number of speaking tasks. Some students (11 voices) still consider that the instructors give too many speaking tasks in the classes. They might think that too many speaking assignments dominate the class activities in a way that other language points (such as grammar or others) are not given equal proportion during the lessons. However, the voices only represent a relatively small number of students, and thus can not represent the majority of the students' voices. What can be concluded here is that there are still some students who object to the large number of speaking activities in the class, and should be thus balanced in proportion with other language points in the classroom. Other minor criticisms include the non-academic aspects, such as problems with instructors' class attendance, and absences of Binusmaya participation.

The biggest suggestions to the teaching aspects are surprisingly voices that encourage English Entrant run as the way it does now, or even better (total 17 voices). This means that there are students who are already satisfied with the running of the teaching aspects in English Entrant, and thus think that it should be maintained or even enhanced better. Only few voices encourage the scoring generosity of the instructors, which mean that these students might think that they perform under the standards, and thus, expect their instructors to be more 'generous' in giving scores, rather than make their own efforts to improve their skills.

The highest appreciation on the course contents in English Entrant is for the speaking format (total 38 voices). A wide variety of speaking tasks is employed in the curriculum, ranging from pair work (e.g. telephoning, negotiating, telephoning, etc), group work (e.g. socializing, meeting, etc) to individual presentations. The primary focus on speaking skill rather than on other skills might be the reason why these students prefer this particular aspect in the curriculum. Compared to grammar, the speaking skill does not have to put the emphasis on accuracy, but fluency and clarity. Students might feel encouraged to know that since speaking skill is the most dominating aspect in the lesson, it also contributes significantly to the total score they will get in the end of semester, and as a result, they feel motivated to perform their best in this skill, and thus give their appreciation on this. They also give good appreciation (17 voices) to the GSLC (Guided Self-Learning Class) format. They might like the freedom to learn by themselves in the GSLC sessions. As specified in the curriculum, during GSLC, the students are expected to do essay writing and some reading activities, which are preferably done at their convenient places and times.

The biggest criticism to the course contents (and so far, the highest of all aspects) is in the listening skill format (26 voices). Many factors can contribute to the problems, such as inadequate tools available in the standard classrooms, visits to laboratories, which is located in one campus only, and difficulty of the listening materials in which the speech is considered too fast and unclear. This indicates that these students prefer skills which do not require very much of the thinking process and less appreciate the ones that are difficult in nature, such as listening for note-taking or listening for information. Some negative feedbacks are also directed to the speaking format (8 voices) and writing format ( 6 voices). However, these voices are relatively small in number, and thus cannot represent the voices of the majority in general.

The most suggestions made to the course contents in English Entrant (12 voices) is for the listening skill format. They tend to suggest improvements in quantity and quality. Though they do not mention the specific things, but based on the data of their criticism, it might concern the tools and facilities, such as the class speakers, which are frequently found to be inadequate in number or defect in functions. Another thing might be the visits to laboratories, which are only two rooms in number and located only in one campus, so that they might have to use them in long turns, or in a hurry. The quality aspect might concern the level of difficulty of the listening materials, which are thought by 
these students to be too fast and not clear in the utterances although the materials chosen are designed for beginner-level students. This shows that these students are not really familiar with English, and shows reluctance to comprehend even simple listening discourses in a foreign language. Other few suggestions are directed to other skills, such as more speaking activities and improved reading activities, in which the latter is always the problem of many Indonesian students who do not have a tradition of a good reading habit.

The highest appreciation (24 voices) to the independent learning system of English Entrant is directed to speaking activities beyond class hours, either in speaking tutorial program (EESE) organized by the university or in English extra-curricular activities organized by BNEC (Bina Nusantara English Club). For students who like these speaking activities, the strongest factor might be the informality, since the program is conducted by fellow students, the fun atmosphere must come into play among participants, such as simple chit-chat, games, or problem-solution discussions.

As for the criticism, several students (11 voices) do not show their preferences over the reading journal activities. As discussed previously, this might be linked with the not-so-good reading habit among Indonesian students. The speaking tutorial program (EESE), and extra-curricular activities (BNEC) are also criticized by these students (11 voices). This might be related to the next criticized aspect, which is lack of feedback input and monitoring process, especially from the instructors (6 voices). This can be understandable since the ones who guide the activities are mostly fellow students who are probably more proficient in English skills than the participants, but not yet experienced in teaching and guiding. Few students also object to the essay writing assignments during GSLC and listening practice at laboratories. Again, this might also relate to the not-so-good habit of independent learning among these students. This type of students prefers the learning experiences under the direct guidance and supervision of experts, like professional lecturers.

Very few suggestions are made towards the independent learning system of English Entrant. Around 8 students think that the whole system of independent learning should be maintained and improved. Few students suggest that reading activities and listening practice be done in classes rather than in homes or at laboratories. Again, this type of students might object to the independent learning mode, as it might conflict with their common preferences and style in learning. Other few suggestions are made to the speaking tutorial and extra-curricular activities. This might also relate to next suggestions in which more fun factors and games be integrated in such activities. This means that these students might consider that the independent learning system should be different from the standard classroom environment, and thus requires more informality degree and fun aspects in such settings.

\section{CONCLUSION}

Findings on the teaching evaluation of English Entrant indicate as follows. Teaching methodology of communicative language approach tends to be appreciated highly by these students, since it employs more of speaking practice in the classroom rather than other skills like reading, writing and listening. Instructors, who play roles not only as lecturers but also as parents, older brother/sister, and sometimes friends, tend to be preferred highly by these students, because these instructors manifest likable personalities, like friendliness, kindness and a certain degree of intimacy. There are some students who disagree with the number of speaking tasks in the classroom, and thus, request that it needs to be balanced in proportion with other important language points. There are a number of students who think that the teaching aspect of English Entrant is already running well and thus should be maintained as the way it is, or even enhanced better in the future. 
Findings on the course content evaluation of English Entrant show as follows. The speaking format, which employs a wide variety of tasks ranging from pair work, group work to individual presentations, receives much appreciation from these students, since it puts the emphasis on fluency and clarity rather than accuracy (grammar). The listening format receives much criticism from these students due to some reasons, such as inadequate and limited number of tools and facilities (laboratories) and the high degree of difficulty of the listening materials. Some suggestions are directed to the listening activities both in quantity and quality, for example improved class speakers, more laboratories available, lower level of listening materials, etc.

Findings on the independent learning system evaluation of English Entrant tell as follows. Speaking activities, which are guided by fellow students and organized under programs of EESE and BNEC (Bina Nusantara English Club), receive appreciation from these students, since the fun factors are quite prevalent in the learning atmosphere, such as chitchats, games, info sharing, etc. Reading journal activities and speaking activities also receive some criticism from these students, since there is a lack of feedback input and monitoring process, especially from lecturers. Very few suggestions are made towards the independent learning system.

\section{Suggestions}

The findings of the qualitative analysis have generated some valuable input and implications for the ELT contexts at Binus University. Those are: highly communicative instructors and engaging teaching methodology tend to be highly acceptable for students of English Entrant; fluency and clarity aspects in speaking tasks are more appreciated by these students rather than the grammatical aspects. The listening format is better improved in quality and quality, while the writing and reading practice can be continuously delivered beyond-class hours but enriched with adequate resources and feedback monitoring; the independent learning system will be more appreciated by these students if more feedback input is available through academic monitoring system, and the instructors (fellow students) are continuously trained in teaching expertise and language skills, so that they can be more competent and prepared for guiding the activities.

\section{REFERENCES}

Breen, M. (n.d). A Pragmatics of Language Teaching: From Practice to Principles. In Richard, J. C. (2001). Curriculum Development in Language Teaching. Cambridge: Cambridge University Press.

Brindley, G. (1984). Needs Analysis and Objectives Setting in the Adult Migrant Education Program. In Richard, J. C. (2001). Curriculum Development in Language Teaching. Cambridge: Cambridge University Press.

Brown, K. L. (2003). From teacher-centered to learner-centered curriculum: improving learning in diverse classrooms. Education, 124(1), 49-54.

Cohen, L., Manion, L., et al. (2000). Research Methods in Education. London: Routledge Farmer.

Harmer, J. (2007). The Practice of English Language Teaching. Essex: Pearson Education.

McCombs, B. L. (1997). Self-assessment and reflection: tools for promoting teacher changes toward learner-centered practices. In Brown, K. L. (2003). From teacher-centered to learner-centered curriculum: improving learning in diverse classrooms. Education, 124(1), 50. 
McCombs, B. L., \& Whistler, J. S. (1997). Learner-centered classroom and schools: strategies for increasing student motivation and achievement. In Brown, K. L. (2003). From teachercentered to learner-centered curriculum: improving learning in diverse classrooms. Education, 124(1), 49.

McLean Orlando, S. (2006). The Importance of Informal Learning in EFL. In Harmer, J. (2007). The Practice of English Language Teaching. Essex: Pearson Education Limited.

Richard, J. C. (2001). Curriculum Development in Language Teaching. Cambridge: Cambridge University Press.

Siemon, A. (2010). Learning English in China: is communicative language teaching a reality? Australian Journal of Language and Literacy, 33(2), 39-42.

Usher, R. (1996). A critique of neglected epistemological assumptions of educational research. In D. Scott and R. Usher (eds), Understanding educational research. London: Routledge. 